Article

\title{
Hostile Natives: Violence in the Histories of American and Japanese Nativism
}

\author{
Mark Thomas McNally \\ Department of History, University of Hawai‘i at Mānoa, Honolulu, HI 96822, USA; mmcnally@hawaii.edu
}

Received: 18 April 2018; Accepted: 17 May 2018; Published: 18 May 2018

check for updates

\begin{abstract}
This article shows how inaccurate the category of nativism-derived from American historiography-is when applied to the Japanese context prevailing when National Learning (Kokugaku) was flourishing. It argues that violence is not a distinctive feature of Kokugaku and suggests that the association between nativism and Kokugaku in Japanese studies is flawed. This is further complicated by examining instances of physical violence directed at foreigners and Japanese alike, which surged during the final years of the Tokugawa shogunate, when the slogan "revere the emperor and expel the barbarian" (sonnō-jō'i) resulted in extreme violence and assassinations. Victims of such attacks were not limited to Westerners, since Katsu Kaishū was almost killed by Sakamoto Ryōma. While significant portions of the Japanese elite began to advocate opening the country (kaikoku), many among them remained divided in their attitude toward Western learning and its necessity. This leads to the conclusion that Kokugaku was not an example of Tokugawa nativism, let alone the example of Tokugawa nativism, and that it would be better to develop a hybrid category of nativism applicable to that era. Such category results from combining Ralph Linton's concept of nativism with John Higham's characterization of nativism as marked by extreme hostility.
\end{abstract}

Keywords: nativism; violence; xenophobia; Japanese history; American history; Kokugaku; National Learning; expulsion of foreigners (jón'i); Meiji era (1868-1912); Tokugawa period (1600-1867)

\section{Introduction}

Nativism occupies a notorious place in American history. It is a term that originally referred to the hostility of American Protestants to the arrival of Catholic immigrants in the mid-nineteenth century. In Japanese history, nativism is commonly used, with some exceptions, as the historiographical classification of the Tokugawa intellectual institution known as National Learning (hereafter referred to as Kokugaku), the followers of which glorified Japan's past as the solution to the social problems of the day, a solution that manifested chiefly in the denigration of foreign influences. The thoroughly scholarly character of Kokugaku contrasts sharply with the main nineteenth-century American nativist movement, the Know-Nothings, whose hostility toward Catholic immigrants was legendary. ${ }^{1}$ Indeed, violence was a hallmark of American nativism, not just by the Know-Nothings and their ilk, but also by their twentieth-century successors, the Ku Klux Klan. With the exception of some overzealous followers involved in the "separation of Shinto from Buddhism" (shinbutsu bunri) movement of the Meiji era (1868-1912), ${ }^{2}$ violence is not something that scholars associate with Kokugaku. This conceptual gap, revolving around the issue of violence, indicates that the association between nativism and Kokugaku in Japanese studies is flawed. ${ }^{3}$ Thus, using the conceptual motif of violence, I argue in this essay that

\footnotetext{
See Herbert Asbury's Gangs of New York (Asbury 2008), which Martin Scorsese adapted for the 2002 film.

For more information on the role of Kokugaku in shinbutsu bunri, see (Hardacre 1989).

(McNally 2016).
} 
late-Tokugawa Japan was replete with instances of nativism that more closely comport with the ways in which nativism is understood outside of Japanese studies.

At the same time, one of the distinguishing features of Bakumatsu (1853-1867) history-the final years of the Tokugawa shogunate-was the movement known as "revere the emperor and expel the barbarian" (sonno-jō'i $i$ ), in which extreme violence, usually at the hands of "gentlemen of high purpose" (hereafter referred to as the shishi), was directed at Westerners in Japan, and for which nativism seems a more appropriate classification. By focusing on the issue of physical violence, we can begin the process of diverting the attention of those interested in nativism away from Kokugaku, a trend that in some ways started more than a decade ago, ${ }^{4}$ and toward Bakumatsu political history, specifically the concept of "expulsion" (hereafter referred to as $j \bar{o}^{\prime} i$ ).

\section{A Note on Theory and Methodology}

The connection between Kokugaku and nativism, whether as a categorization or as a translation, is not fixed and unchanging, as it involves, to use Saussure's terminology, the assignation of one or more signifiers (words) from one culture, along with their corresponding signifieds (meanings), to the signifiers and signifieds of another culture. ${ }^{5}$ Saussure famously argued that the linguistic relationship between signifiers and signifieds was almost always arbitrary within the same spoken language, so that it is only reasonable to conclude that the same would be true within the context of relating words from one language to those of another. However, in the latter case, these linguistic correspondences are themselves in flux, since words in one language can have multiple translations in another language that change and evolve over time.

Anthropologists who employ the methodology of "cultural materialism" have shown how these fluctuations occur within the scholarly processes of categorization and conceptualization as well. ${ }^{6}$ Simply put, the adherents of cultural materialism posit that similar material circumstances (like colonialism or immigration in the context of this essay) produce similar cultural developments (like nativism). Members of a given culture produce their own words/concepts to describe these developments, and anthropologists refer to these as emics. Analytical observers of this culture, as members of a separate culture (or even cultures), then assign their own words/concepts to describe these same developments, and these are known as etics. Thus, for our purposes in this essay, "nativism" is the etic category that many Japanologists have linked to the emic concept of Kokugaku, a connection that I propose we should sever. As adherents of science, scholars of cultural materialism argue that not only should we expect to find that the etics assigned to any given emics have changed over time, but that these changes are also a natural outcome of the scientific method.

The act of de-linking Kokugaku from nativism constitutes what Thomas Kuhn has famously called a paradigm shift. ${ }^{7}$ Despite the fact that some Japanologists have already begun this process, by focusing on Kokugaku itself, no one has attempted to do the same with nativism during the Edo period. For Kuhn, the intellectual displacement of one paradigm must accompany its replacement with something else. However, it is critical to state at the outset that the analysis of Kokugaku using Western etics (other than nativism) is beyond the scope of this essay. The purpose of this essay is to focus on etic nativism by proposing alternative Japanese emics. At the same time, it is worth noting that a

4 The works with the most influence on the categorization (or even translation) of Kokugaku as nativism are Harootunian (1988) and Nosco (1990). Burns (2003) was perhaps the first scholar to declare that Edo-period Kokugaku was not a kind of nativism, a connection that she suggests emerges in the Meiji period. Wachutka (2013), however, produced a sustained study of Meiji Kokugaku without ever referring to it as nativism. The same is true for Bowring (2017), whose comprehensive study of Tokugawa religious and intellectual history, inclusive of Kokugaku, similarly never refers to it as nativism.

5 See (De Saussure 1993).

6 For the definitive work describing cultural materialism, see (Harris 1979). However, emics and etics first emerged within the field of linguistics with Kenneth Pike as their scholarly pioneer. See (Pike 1971).

7 See (Kuhn 1970). 
paradigm shift of this kind is important because it carries the potential to conceptualize Tokugawa nativism in ways other than as an outlier within global studies of etic nativism.

\section{Nativism's Various Species}

A Philadelphia newspaper editor first used the word nativism in 1844 to signify the phenomenon of American opposition to immigration. Shortly thereafter, opponents of immigration were referred to as nativists, many of whom organized themselves into a secret society, the Know-Nothings. The Know-Nothings were dedicated to ending immigration into the United States and the prevention of immigrants already in the country from becoming American citizens. Since opposition to immigration was clearly at odds with the universalistic and tolerant rhetoric associated with the founding of the United States, it was nearly a century before historians had enough temporal distance to study nativism in any scholarly way; the result was Ray Billington's The Protestant Crusade, 1800-1860: A Study of the Origins of American Nativism, published in 1938. Billington argued that nativism was not so much anti-immigrant in character as anti-Catholic, since the nativists were largely unconcerned with immigrants from Great Britain and Anglophone Canada. ${ }^{8}$ Indeed, for Billington, nativism was synonymous with anti-Catholicism, of which opposition to immigration was but one political by-product.

Five years after the appearance of Billington's monograph, Ralph Linton published a seminal article on nativism, "Nativistic Movements," in American Anthropologist. In this article, Linton greatly expanded on the concept of nativism by removing it from American history and applying it to any encounter between European colonizers and indigenous peoples anywhere in the world, including, interestingly enough, sixteenth-century Japan. Linton acknowledged that hostility was one possible outcome of any such encounter, but it was neither the only one nor even the most interesting. For Linton, the adoption of European culture, chiefly European technology, by indigenous peoples, or "natives," was the chief characteristic of a kind of nativism that emerged from situations in which "no factors of actual dominance [were] involved ... [so that] the inferior group borrows eagerly from the superior one [.]" ${ }^{\prime \prime}$ This interpretation was both more expansive than Billington's and also at odds with it, so that Linton's view of nativism became the etic counterpart to Billington's emic form of nativism. Linton believed that a good place to begin examining Japanese nativism was the mid to late 1500s, when the Japanese adopted European firearms.

John Higham penned perhaps the most influential monograph on American nativism in 1955, Strangers in the Land: Patterns of American Nativism, 1860-1925, a work he revised in 1988. Not surprisingly, Higham synthesized the insights of both Billington and Linton on the phenomenon of nativism, arguing that it was neither reducible to anti-Catholicism nor strictly the result of a colonial context. He believed that nativism was the extremely hostile reaction of the so-called natives to a "minority group on the ground of its foreign (i.e., 'un-American') connections." ${ }^{10}$ It is with Higham that we see an emphasis on violence, both symbolic and physical, as a defining trait of nativism: "Does nativism consist only of the particular complex of attitudes dominant in the anti-foreign crusade of the mid-nineteenth century? Or does it extend to every occasion when native inhabitants of a country turn their faces or raise their hands against strangers in their midst?"11 For Higham, nativism was the domestic counterpart to jingoism, which he saw as the extension of American hostility to nations abroad; in other words, nativism signified a war against foreigners at home while jingoism signified the threat of war abroad. ${ }^{12}$

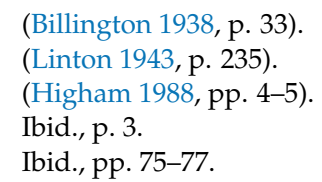


When looking at these three interpretations of nativism, as well as certain variants stemming mostly from Linton's work, it is clear that Tokugawa-era Kokugaku cannot be described as nativism. Although its followers were opposed to all non-Japanese faiths and beliefs, Christianity among them, it was not primarily anti-Christian or anti-Western during its formative period in the eighteenth century. While it would be hard to imagine adherents of Kokugaku welcoming immigrants to Japan, immigration was a non-issue until the conclusion of the Convention of Kanagawa (Nichibei Washin Joyaku) with the Americans in 1854. By then, the last of the canonical figures of Kokugaku, Hirata Atsutane (1776-1843), had been dead for more than a decade. Atsutane, along with the other canonical scholars of Kokugaku, such as Kamo no Mabuchi (1697-1769) and Motoori Norinaga (1730-1801), spent much of their time voicing their opposition to the dominance of foreign ideas in the Japan of their day. There were virtually no foreigners living in Japan at the time, so living among them was also a non-issue, even though Atsutane feared, like many in the early decades of the nineteenth century, that the Russians had designs on Japan. Instead, what inspired their scholarly vitriol the most was the fact that their Japanese contemporaries were either unaware of their own ignorance regarding the prevalence of foreign cultural influences in Japan, like Confucianism and Buddhism, or they were unconcerned about it. In any case, the problem from their perspective lay not with foreigners in Japan but with their fellow Japanese.

A comparison between Billington's understanding of nativism and what we know about the history of Kokugaku during the Tokugawa period reveals a rather wide conceptual gap between the two. There were no papal effigies to be burned in Tokugawa Japan, as delighted as the followers of Kokugaku might have been to indulge in this American pastime. ${ }^{13}$ By greatly broadening the concept of nativism to make it inclusive of phenomena outside of American history, namely, as etic nativism, Linton's work holds more promise for Japanese studies, a fact that some Japanologists have recently recognized. Indeed, the political and even geopolitical contexts of Tokugawa Japan, especially the relationship between Japan and the West, seem to conform more neatly to the colonial encounter envisioned by Linton as the wellspring of nativism, rather than the immigration context examined by both Billington and Higham. However, Linton's focus on cultural adoption-especially with regard to technology—as the defining feature of Japanese nativism, creates conceptual problems for Japanologists, since the followers of Kokugaku railed against cultural adoption.

Although one of the major theorists of nativism, Higham has received little attention among Japanologists, yet his work holds much analytical promise. ${ }^{14}$ Before Higham's concept of nativism can become useful for Japanologists, we must first abandon the context of large-scale immigration that was so critical to the historical context of the American nineteenth century. One could argue that no such condition has ever existed in Japan's recorded history, not even in antiquity, so that the analysis ends before it begins, which might explain why Higham's work has gone virtually unnoticed in Japanese studies. Let us explore whether the conceptual foundation for Higham's interpretation of nativism - the paradigmatic encounter between foreigner arrivals and natives—could serve as a point of embarkation for an analysis of Tokugawa nativism.

The problem with analyzing Kokugaku using etic nativism is that it is relevant to neither immigration nor to face-to-face encounters between foreigners and the Tokugawa Japanese. We must therefore abandon, or at least set aside, much of what we know about the history of Kokugaku, in order to begin applying etic nativism to Tokugawa Japan. While Linton's interest in cultural adoption is of little use in the case of both Tokugawa Japan and Kokugaku, his attention to the context of colonialism is valuable, especially for Bakumatsu Japan. The same is true for the historiographical utility of Higham's emphasis on the extreme hostility engendered by actual interactions between immigrants and natives, as it is much more focused and specific than Linton's overly inclusive view

13 (Billington 1938, pp. 18-19).

14 So far as I can tell, the sole exception to this is Carol Gluck. See (Gluck 1985, p. 324). 
of nativism. It is not possible to substitute one theorist for another, Linton for Higham or vice versa, since both offer useful ideas. What we need to do, therefore, is to draw from their interpretations to develop a hybrid concept, one that would be useful not only for Japanese studies, but also for other fields having nothing to do with either the United States or Japan.

When Higham noted the emergence of hostility among Americans to the arrival of immigrants, he argued that the extremes to which this hostility reached could only be the result of a condition in which the members of both groups lived in close proximity. While the Know-Nothings vociferously denounced Catholic immigrants within the public sphere as a collective threat to Americans both culturally and politically, they were not averse to the use of physical intimidation as a means to achieve their goals. In the decades before the Civil War, the Know-Nothings and their allies forged ties with gangs of street thugs in nearly every major urban area of the North, where there were high concentrations of immigrants, and encouraged them to deal with immigrants in more direct and brutal ways. These gangs readily professed their American authenticity and purity and were more than happy to defend the United States and their fellow Americans against the immigrant horde; not surprisingly, the immigrants formed their own gangs to face off against their nativist foes. The clashes between these gangs turned parts of major American cities, like New York City, into virtual war zones, as Herbert Asbury's The Gangs of New York, portrays in vivid detail:

During the summer of 1834 the opportunities for the gangs to engage in their natural employment were greatly increased by the appearance of two new political groups, the Native Americans [a forerunner of both the Native American Party and the American Party, aka the Know-Nothings] and the Equal Rights Party ... The Native Americans deplored the election of foreigners to office, and vigorously demanded the repeal of the naturalization laws by which Tammany Hall had gained such an enormous following of Irish voters. The Native Americans took the place of the Whigs in some of the municipal elections ... and hired gangsters to blackjack their opponents ... The Bowery gang known as the American Guards, the membership of which prided themselves on their native ancestry, was soon devotedly attached to the Native Americans party ... During the summer of 1835, about a year after the election riots, bitter enmity developed between this gang and the $\mathrm{O}^{\prime}$ Connell Guards ... the particular champion of the Irish element of Tammany Hall. The gangs came to blows on 21 June 1835 at Grand and Crosby streets on the lower East Side. The fighting spread as far as the Five Points ... Dr. W.M. Caffrey, a noted surgeon, was killed by a brickbat while trying to make his way through the mob to attend a patient. ${ }^{15}$

While there is no similarly colorful event from the era of Kokugaku's intellectual development (c. 1690-1840), violent encounters between the Japanese and foreigners began to occur roughly two decades after the gang fight described above. As the Europeans and the Americans began to establish treaty ports and take up residence in Japan beginning in 1856, rogue warriors as well as "masterless samurai" (rōnin) took up arms against these Westerners in an attempt to expel them $\left(j \bar{o}^{\prime} i\right)$, becoming shishi in the process.

\section{Hostility Directed Inward and Outward}

While $j \bar{o}^{\prime} i$ seems to suggest hostility and even violence, and the actions of the shishi and others would certainly bolster this perception, this was not always the case. As Bob Wakabayashi has observed, $j \bar{o}^{\prime} i$ was a term from Chinese antiquity that referred to the Sinicization of the non-Han groups both inside and outside of the imperial Chinese state. ${ }^{16}$ Members of these non-Han ethnic groups intent on adopting Chinese cultural institutions successfully had to purge themselves of their "barbarian"

15 (Asbury 2008, pp. 34-35).

16 (Wakabayashi 1986, p. 21). 
ways first; $j \bar{o}^{\prime} i$, therefore, meant to "expel the barbarian within oneself," filling the resultant cultural void with Chinese civilization. The original concept of $j \bar{o}^{\prime} i$ was a kind of barbarian self-cultivation, having nothing to do with any forced imposition of Chinese culture, let alone physical violence.

Once the concept of $j \bar{o}^{\prime} i$ reached Japan, any trappings of contemplative acculturation were lost over time, and its target - the culture of the barbarian — was replaced with the barbarians themselves, people who had to be driven out of Japan. Tokugawa intellectuals, along with the political leaders they served, such as Tokugawa Nariaki (1800-1860), argued that the imperative to bring about $j \bar{o}^{\prime} i$ in the 1850s was actually the latest such instance in a long history of successful expulsions of Westerners from Japan's shores dating back to the sixteenth and seventeenth centuries. ${ }^{17}$ For Nariaki, $j \bar{o}^{\prime} i$ was a political necessity not only as a means of preserving Japan's territorial integrity; it was also intimately connected to the Bakufu's policies of geopolitical isolation, what was known as sakoku in Nariaki's time. In 1825, under the influence of Nariaki's scholarly advisor, Aizawa Seishisai (1781-1863), the Bakufu ordered domains with coastal frontiers to shoot at foreign ships attempting to enter Japanese waters, and to kill any foreigner who managed to land on Japan's shores; this was known as the Expulsion Edict (Munen Uchiharai no Rei). By the time of Commodore Matthew Perry's (1794-1858) arrival in 1853 , the association of $j \bar{o}^{\prime} i$ with the violent expulsion of Westerners from Japan was something with which members of the warrior class were already familiar.

Although the Convention of Kanagawa of 1854, and the Treaty of Amity and Commerce (Nichibei Shūkō Tsūshō Jōyaku) of 1858, were concluded between the Americans and the Tokugawa Bakufu, they initially lacked any support from the imperial court; in fact, Emperor Kōmei (1831-1867), under the influence of Mito scholars like Aizawa Seishisai, was openly opposed to any such treaty. The absence of imperial approval for these treaties, as well as those concluded with the other Western powers, was critical, since it gave warriors the justification they needed for carrying out $j \bar{o}^{\prime} i$ in the emperor's name. The warriors who dedicated themselves to the emperor at this time, the shishi, relished the personal, face-to-face kind of confrontation with Westerners envisioned in the Expulsion Edict, which called on warriors to dispatch any foreigners who had actually landed in Japan. Unfortunately for the shishi, the killing of Westerners in Japan after 1856 represented a conflation of Bakufu-approved $j \bar{o}^{\prime} i$ with court-approved $j \bar{o}^{\prime} i$. This fact made life for the shishi quite dangerous, and once imperial approval for the treaties was finally secured, they became targets themselves.

The assassination of Henry Heusken (1832-1861) is a good example of how brutal and deadly a shishi encounter could be for a Westerner during the Bakumatsu era. Heusken was a Dutch interpreter who worked for Townsend Harris (1804-1878), the first American consul to the Tokugawa Bakufu. Attacks on Westerners by the shishi began soon after Westerners began landing on Japanese soil. The celebrated patriot, Sakamoto Ryōma (1836-1867), vowed to behead any Westerner in Japan shortly after hearing about the arrival of Perry in $1853,{ }^{18}$ and Ryōma was certainly not the only warrior who harbored such feelings, so it likely came as no surprise to anyone that such attacks actually occurred during the latter half of the 1850s. Harris warned his staff not to return at night to Zenpukuji, where the American legation was housed, for fear of falling victim to the sword of some shishi bent on carrying out $j \bar{o}^{\prime} i$. Undaunted, Heusken accepted a dinner invitation on 15 January 1861, returning, against Harris's admonitions, to Zenpukuji with only his two Bakufu escorts. A group of black-clad warriors descended on Heusken and his guards and the ensuing encounter went very badly for Heusken:

Two of the masked swordsmen almost simultaneously attacked Heusken from both sides. The first to reach him thrust his sword upward from the left. To parry the attack, Heusken jerked his body to the right, thus exposing himself to the attacker on the other side. The man on his right swept his sword upward, slashing Heusken deeply as the Dutchman spurred his horse to escape. The attack happened so fast and his horse obeyed so well that Heusken's

17 (Tokugawa 1976, pp. 10-11).

18 (Iwasaki 1926, p. 36). 
first reaction was one of relief to have escaped the thrust from the side. Only when the horse galloped a few paces did he begin to feel pain ... [After dismounting,] Heusken lay mortally wounded in the street. ${ }^{19}$

Heusken lingered for several hours before finally bleeding to death.

Yet the victims of attacks by the shishi were not limited to Westerners. Katsu Kaishū (1823-1899), the founder of the Bakufu's first navy, came close to falling victim to Sakamoto Ryōma's blade. As Kaishū recalled, "Sakamoto had come [to my home] to kill me-what a formidable man! (At that time, I received him with a smile on my face). He calmed down and found it difficult to strike at me. [I could see that] he had a charisma [about him] and was a capable [man]." ${ }^{20}$ After some quick thinking and fast talking, he managed to win over Ryōma to his point of view, and Ryōma later pledged himself to Kaishū's teaching. ${ }^{21}$ Ryōma himself was not quite so lucky as his teacher; he fell to an assassin's sword in a Kyoto inn in December of 1867. Sakuma Shōzan (1811-1864), whose teachings inspired Kaishū's pro-"open the country" (hereafter referred to as kaikoku) views, was cut down by a renowned swordsmen three years after Heusken's assassination, while another famous Japanese victim of the shishi, Ii Naosuke (1815-1860), the Great Elder (tairō) and de facto leader of the Bakufu, was killed by warriors from Mito and Satsuma less than a year before Heusken's death. At the same time, the activities of the $j \bar{o}^{\prime} i$ supporters were not confined to such personal, face-to-face attacks as those carried out by the shishi. In 1863 and 1864, the daimyo of Chōshū, Mōri Takachika (1819-1871), operating under the direction of the imperial court, ordered his units manning the domain's coastal batteries to attack Western ships attempting to pass through the Straits of Shimonoseki. These attacks prompted two Western military campaigns against Chōshū, which resulted in the destruction of its coastal batteries and its temporary military occupation. Ironically, Chōshū's initial attacks in the cause of $j \bar{o}^{\prime} i$ against Western shipping seeking passage through the Inland Sea were not only militarily unsuccessful, they actually led directly to Western military forces landing in Japan. Rather than prevent or preempt an invasion, these attacks precipitated one.

An analytical focus on violence helps us hone etic nativism in ways that make it more historiographically useful for Japanologists, while, at the same time, opening up avenues for applications that are both unprecedented and also more congruent with the ways nativism is understood outside of Japanese studies. This brings us to one final note: while advocates of expulsion during the Bakumatsu era envisioned the use of violence to force the immediate withdrawal of Westerners from Japan, their kaikoku rivals wanted to use Western technology to effect a withdrawal in the future using the threat of violence. In this way, the advocates of kaikoku were no less nativistic than their counterparts who advocated $j \bar{o}^{\prime} i$, since they supported the violent expulsion of Westerners from Japan at some point in the future.

Both Katsu Kaishū and Sakuma Shōzan were targets for assassination by shishi supporters of $j \bar{o}^{\prime} i$, the former nearly succumbing to the blade of Sakamoto Ryōma while the latter famously fell at the hands of another shishi. The life-and-death stakes of the political opposition between the supporters of $j \bar{o}^{\prime} i$ and kaikoku might lead us to conclude that such an opposition also manifests itself within the history of Bakumatsu nativism, such that the latter must signify some kind of cosmopolitanism, the conceptual polar opposite of etic nativism. This is not the case, since many of the leading figures of kaikoku, such as Sakamoto Ryōma, Sakuma Shōzan, and Katsu Kaishū, supported the Westernization of Japanese military forces in order to assert Japan's political autonomy from Western domination, not welcome further incursions that would potentially deepen it. Kaishū argued that fortifying Japan's

\footnotetext{
(Hesselink 1994, p. 333).

(Kikuchi and Yamamura 1996, p. 75).

21 Kaishū managed to convince Ryōma to hear him out on the merits of kaikoku before carrying out his goal of assassination. Ryōma listened and was so moved by Kaishū's words that he declared himself to be one of Kaishū's students, in what amounted to a spectacular conversion from jó'i to kaikoku. Kaishū's powers of persuasion also won over the radical Kyoto aristocrat Anegakōji Kintomo (1840-1863). See (Kikuchi and Yamamura 1996, p. 94).
} 
coastal defenses, even with the latest Western artillery batteries, had failed and would continue to fail to keep the Westerners at bay, since the only truly effective way to engage them was on equal terms at sea. ${ }^{22}$ Indeed, the landing of Western troops in Chōshū in 1863 and 1864 demonstrated just how prescient Kaishū's views really were. For Kaishū, kaikoku was a means to an end, not the end itself. As scholarly as Katsu Kaishū was, he was also a practical person who advised the Bakufu in how to apply Western military technology for its own political interests and survival.

\section{Ambiguous Attitudes toward Western Learning}

Kaishū's contemporary, Sakuma Shōzan, ${ }^{23}$ was tasked with studying Western learning by his lord, Sanada Yukitsuru (1791-1852), the daimyo of Matsushiro. He did so as an open-minded, if perhaps somewhat skeptical, Confucian. Many of Shōzan's contemporaries found much about Western learning that was a threat to both Sinocentrism and Confucianism, a feeling that had circulated among intellectuals in the previous century, some of whom linked the obvious superiority of Western science and technology to the superiority of some underlying intellectual framework, some Western analog to Confucianism. Rather than learn about Western science and technology and engage with it, even if only to refute it, a task undertaken by many Kokugaku scholars in the early decades of the nineteenth century, ${ }^{24}$ many Confucians of Shōzan's generation sought to obliterate it completely from Japan and to repudiate its ideological supporters, but Shōzan was not one of them.

For Shōzan, there were two classical imperatives that the Confucian study of Western learning fulfilled. In the first place, Confucian scholars could justify the study of Western knowledge by invoking the maxims of Sunzi (544-496 BCE) regarding the need to know one's enemy before going into battle, a view with which Shōzan heartily concurred. ${ }^{25}$ For Shōzan, understanding the enemy's culture gave one insight into their mindset, which is why he encouraged his young protégé, Yoshida Shōin (1830-1859), to try and board one of Commodore Perry's vessels and return with it to the United States. ${ }^{26}$ Studying the technical products of this mindset yielded other more obvious benefits, and Shōzan was in agreement with Katsu Kaishū on this issue. ${ }^{27}$ A second classical justification for the study of Western knowledge by Confucian scholars was that it conformed to the Song-dynasty Neo-Confucian pursuit known as "the investigation of things and the exhaustion of principle" (kakubutsu kyüri). ${ }^{28}$

For Shōzan and the other leading intellects of kaikoku, the study of Western knowledge was in no way an idle pursuit, namely, knowledge for its own sake. Westerners, while an intelligent and technically savvy people, were ultimately treacherous and untrustworthy. ${ }^{29}$ If given the choice, the Japanese people should never deal with such an amoral and even immoral people, but they were at a significant disadvantage technologically speaking, and the only way to close that gap was to open Japan to them. Opening the country served the dual purpose of staving-off any invasion in the short term while also providing the political respite necessary to study Western ways. Shōzan illustrated for the lord of Matsushiro, following the arrival of Townsend Harris in 1856, the dire situation of the Japanese people using a parable from Chinese history in which a small realm in antiquity understood

22 Ibid., p. 95.

23 All citations for Sakuma Shōzan are in (Satō et al. 1971).

24 Motoori Norinaga famously admonished his students to undertake the study of Rangaku in their efforts to glorify the kami, who were responsible for all of creation, even the Westerners and their technology. See (McNally 2005).

25 (Sakuma 1971c, pp. 247-48). Note that Aizawa Seishisai, the leading intellectual of Bakumatsu Mitogaku, and another convert from $j \bar{o}^{\prime} i$ to kaikoku, made similar observations about the need to know about one's enemies. See (Aizawa 1973, p. 363).

26 (Jansen 2000, p. 289). Shōin's attempt failed, and both he and Shōzan were arrested and imprisoned by Bakufu authorities.

27 (Sakuma 1971b, p. 323).

28 Although he did mention kakubutsu kyūri specifically in another section of the Seikenroku, it is clear that his admonition to seek out knowledge about the West, whether directly relevant to its technology or not, resonates with it as well. See (Sakuma 1971c, p. 240).

29 (Sakuma 1971a, p. 296). 
the folly of attacking its larger and more powerful neighbors. ${ }^{30}$ His point, however, was not that the Japanese would always be weaker than their Western enemies; once the modernization of their military forces was accomplished, and the Japanese people were more familiar with Western customs and values, they would be able to assert Japan's international autonomy. The Japanese would be able to do this, Shōzan and others believed, either by the use or threat of violent force, but this process had to begin by opening the country in the present:

[By combining East and West], the developments of the myriad realms will be gathered together, and the territory of foreign realms, as well as that of Japan, will gradually be opened [to the rest of the world]. The realm's strength will emerge above that of the myriad realms, our gun repairs and ammunition manufacture will emerge above that of the myriad realms; the numbers of our warships will exceed that of the myriad realms; the numbers of talented warriors will exceed that of the myriad realms; the expertise of our soldiers will exceed that of the myriad realms; and the steadfastness of our fortifications will exceed that of the myriad realms. If these were to [come to pass], then those realms that have harbored ill will [toward us] will fear [us] and not await [the Bakufu's] refusal [of their demands] ... They will yearn for [the Bakufu's] edification, and obey [it] by cultivating service [to it]. ${ }^{31}$

\section{Conclusions}

The connection between $j \bar{o}^{\prime} i$, whether immediate or deferred, and violence, whether of the up-close-and-personal kind or the at-a-distance variety, is undeniable, and it is something that makes the Bakumatsu era such a colorful and interesting time in Japan's history. Northern American cities in the mid-nineteenth century were also turned into battlegrounds from time to time between immigrant gangs and their nativist enemies. Thus, violence and the arrival of foreigners were experiences shared by both the Americans and the Japanese of the 1850s and 1860s.

Ray Billington mentioned the hostile and even violent, if only in a symbolic way, aspects of the activities of Americans opposed to the Pope and the Catholic Church. He was, however, less interested in cataloging the depth or breadth of this hostility as he was focused on demonstrating how widespread anti-Catholicism was in the United States before the Civil War. Since his concerns were narrowly focused on America, we can think of Billington's work as the description of emic nativism. The anthropologist Ralph Linton found the phenomenon of nativism so compelling that he revised Billington's conception to include case studies outside the U.S., thereby creating etic nativism and isolating nativism's paradigmatic structure to the encounter between members of different societies. In his close analysis of the nature of these encounters, Linton, like Billington, mentions the role of hostility and violence without any special emphasis; if anything, Linton emphasized the non-violent adoption of technology as the most interesting outcome of any intercultural encounter in which actual domination had yet to develop. It was John Higham, whose monograph on American nativism earned for him the reputation as its leading authority, who foregrounded violence as a hallmark of nativism, not only of American nativism but also of etic nativism in general.

Despite Higham's contributions to the study of nativism, the field of Japanese studies has focused its attention almost exclusively on Edo-era Kokugaku as Japanese nativism. For Higham, Kokugaku would no doubt not qualify as nativism at all, since its followers had virtually no significant connection to foreigners in Japan, and it was the face-to-face encounters engendered by interactions between the two groups that, for Higham, fueled etic nativism with the negative emotions needed to culminate in violence, even though Higham observed how contemporary forms of nativism in the United States more often take the forms of symbolic violence, specifically as racial/ethnic bias and prejudice. As the religious historian John Breen and others have argued, the field of Japanese studies has relied on Linton

30 (Sakuma 1971b, p. 321).
31 Ibid., pp. 323-24. 
for its conceptual guidance on the phenomenon of nativism, ${ }^{32}$ yet Kokugaku bears no striking family resemblance to Linton's emphasis on technological adoption; not surprisingly, Linton observed how the adoption of European technology by the Japanese in the sixteenth century was the paradigmatic example of premodern Japanese nativism, not Kokugaku.

Kokugaku was not an example of Tokugawa nativism, let alone the example of Tokugawa nativism. By using the colonial context from Linton's version of etic nativism and combining it with Higham's emphasis on extreme hostility as the chief characteristic of etic nativism, we have developed a hybrid form of etic nativism applicable to Tokugawa Japan. Wielding such a concept effectively pulls the attention of Japanologists away from Kokugaku and pushes it toward the events and personalities associated with $j \bar{o}^{\prime} i$, and even kaikoku, during the Bakumatsu era.

One might wonder whether the extent to which the effort to work toward a common understanding of a phenomenon like nativism is either relevant or important to our own contemporary times. The movements of peoples, whether as refugees or immigrants, continues to occur in ways both reminiscent of the past and also radically divergent from it. Nonetheless, encounters between members of different societies and cultures is ongoing, and so coming to terms with the ways in which these interactions generate friction, and even violence, is critically important, as it gives policy makers and others the means by which they can anticipate and more effectively deal with it. Establishing a common conceptual framework via etics, so that apples-to-apples comparisons are made rather than those of apples-to-oranges, is the essential first step in this endeavor.

Conflicts of Interest: The author declares no conflict of interest.

\section{References}

Aizawa, Seishisai. 1973. Jimusaku 時務策. In Mitogaku 水戸学. Nihon Shisō Taikei 日本思想大系. Edited by Bitō Masahide, Imai Usaburō and Seya Yoshihiko. Tokyo: Iwanami, vol. 53.

Asbury, Herbert. 2008. The Gangs of New York: An Informal History of the Underworld. New York: Vintage. First published 1928.

Billington, Ray. 1938. The Protestant Crusade, 1800-1860: A Study of the Origins of American Nativism. New York: Rinehart.

Bowring, Richard. 2017. In Search of the Way: Thought and Religion in Early-Modern Japan, 1582-1860. Oxford: Oxford University Press.

Breen, John. 2000. Nativism Restored. Monumenta Nipponica 55: 429-39. [CrossRef]

Burns, Susan. 2003. Before the Nation: Kokugaku and the Imagining of Community in Tokugawa Japan. Durham: Duke University Press.

De Saussure, Ferdinand. 1993. General Course in Linguistics. Edited by Charles Bally and Albert Sechehaye with the collaboration of Albert Riedlinger. Translated and Annotated by Roy Harris. La Salle: Open Court.

Gluck, Carol. 1985. Japan's Modern Myths: Ideology in the Late Meiji Period. Princeton: Princeton University Press.

Hardacre, Helen. 1989. Shinto and the State, 1868-1988. Princeton: Princeton University Press.

Harootunian, Harry. 1988. Things Seen and Unseen: Discourse and Ideology in Tokugawa Nativism. Chicago: University of Chicago Press.

Harris, Marvin. 1979. Cultural Materialism: The Struggle for a Science of Culture. New York: Vintage.

Hesselink, Reinier. 1994. The Assassination of Harry Heusken. Monumenta Nipponica 49: 331-51. [CrossRef]

Higham, John. 1988. Strangers in the Land: Patterns of American Nativism, 1860-1925. New Brunswick: Rutgers University Press.

Iwasaki, Hideshige, ed. 1926. Sakamoto Ryōma Kankei Monjo 坂本龍馬関係文書. Tokyo: Nihon Shiseki Kyōkai, vol. 1.

Jansen, Marius. 2000. The Making of Modern Japan. Cambridge: Belknap Press of Harvard University Press.

32 (Breen 2000, p. 430). 
Kikuchi, Akira, and Tatsuya Yamamura, eds. 1996. Sakamoto Ryōma Nikki 坂本龍馬日記. Tokyo: Shin Jinbutsu Ōraisha, vol. 1.

Kuhn, Thomas S. 1970. The Structure of Scientific Revolutions, 2nd ed. Chicago: University of Chicago Press.

Linton, Ralph. 1943. Nativistic Movements. American Anthropologist 45: 230-43. [CrossRef]

McNally, Mark. 2005. Proving the Way: Conflict and Practice in the History of Japanese Nativism. Cambridge: Harvard University Asia Center.

McNally, Mark. 2016. Like No Other: Exceptionalism and Nativism in Early Modern Japan. Honolulu: University of Hawaii Press.

Nosco, Peter. 1990. Remembering Paradise: Nativism and Nostalgia in Eighteenth-Century Japan. Cambridge: Council of East Asian Studies, Harvard University.

Pike, Kenneth. 1971. Language in Relation to a Unified Theory of the Structure of Human Behavior, 2nd rev. ed. The Hague: Mouton.

Sakuma, Shōzan. 1971a. Harisu to No Sesshōan Ni Kansuru Bakufu Ate Jōshokō ハリスとの折衝案に関する幕府 宛上書稿. In Nihon Shisō Taikei 日本思想大系. Tokyo: Iwanami, pp. 291-98.

Sakuma, Shōzan. 1971b. Jō’i No Sakuryaku Ni Kansuru Hanshu Ate Tōshinsho 攘夷の策略に関する藩主宛答申 書. In Nihon Shisō Taikei 日本思想大系. Tokyo: Iwanami, pp. 321-24.

Sakuma, Shōzan. 1971c. Seikenroku 省録. In Nihon Shisō Taikei 日本思想大系. Tokyo: Iwanami, pp. 237-60.

Satō, Shōsuke, Michiari Uete, and Muneyuki Yamaguchi, eds. 1971. Watanabe Kazan, Takano Chōei, Sakuma Shōzan, Yokoi Shōnan, Hashimoto Sanai 渡辺華山 高野長英 佐久間象山 横井小楠 橋本左内. Nihon Shisō Taikei 日本思 想大系. Tokyo: Iwanami, vol. 55.

Tokugawa, Nariaki. 1976. Jūjō goji kengishō 十条五事建議書. In Bakumatsu Seiji Ronshū 幕末政治論集. Nihon Shisō Taikei 日本思想大系. Edited by Satō Seisaburō and Yoshida Tsunekichi. Tokyo: Iwanami, vol. 56, pp. 9-18.

Wachutka, Michael. 2013. Kokugaku in Meiji-Period Japan: The Modern Transformation of "National Learning" and the Formation of Scholarly Societies. Leiden: Global Oriental.

Wakabayashi, Bob. 1986. Anti-Foreignism and Western Learning in Early Modern Japan: The New Theses of 1825. Cambridge: Council on East Asian Studies, Harvard University.

(C) 2018 by the author. Licensee MDPI, Basel, Switzerland. This article is an open access article distributed under the terms and conditions of the Creative Commons Attribution (CC BY) license (http:/ / creativecommons.org/licenses/by/4.0/). 